\title{
HIV/AIDS and human rights in the third world
}

by Dr Dayanath Jayasuriya

The author calls for a concerted attack on the root causes of poverty, poor governance, and slow infrastructure development to combat the growth of HIV/AIDS.

A few weeks ago, newspapers in several countries carried the photograph of a 12-year-old black South African boy, Nkosi Johnson, who had died of AIDS. He had already become a hero. He had openly accused the South African President, at the AIDS Conference in Durban in July 2000, for the failure to supply pregnant mothers with the drugs that can help prevent the infants from being infected. His white foster mother found herself before the South African Human Rights Commission facing charges from a black doctor for abusing the child for financial gain, a charge she vehemently denied. Photographs of the dying child were alleged to be those of a child suffering from constipation rather than of AIDS.

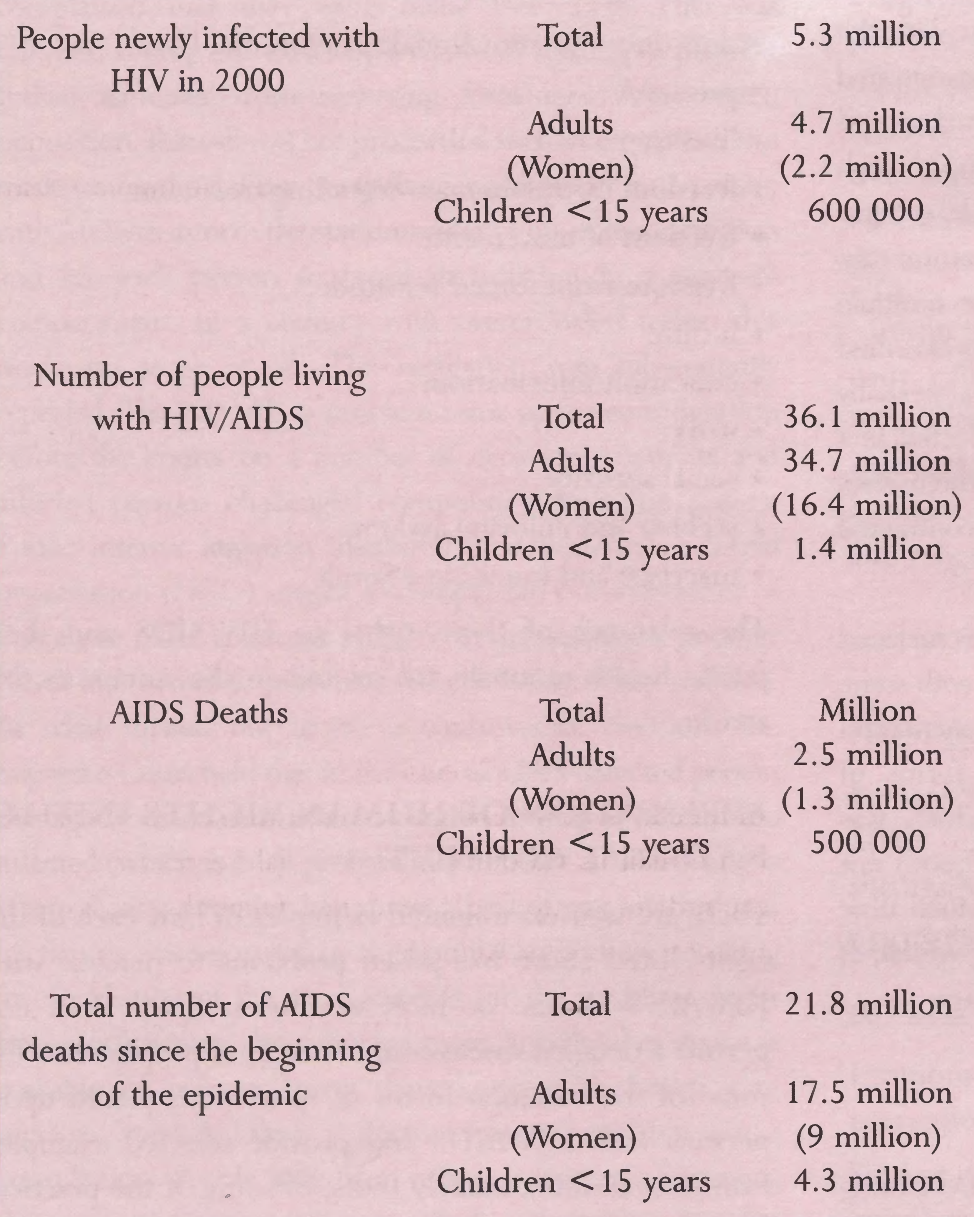

When the first AIDS cases were detected among a group of American gay men way back in 1981, and cases were soon found in Zaire and other African countries, the medical problem of HIV/AIDS acquired a new dimension. Infected persons and their families or partners were soon victimised. Acts of discrimination went beyond individuals: even nations became the subject of travel and other restrictions (for example, the ban on the importation of US blood).

20 years into the epidemic, the saga continues to generate a bewildering array of data on the magnitude of the problem. While under-reporting and under-diagnosis were problems that for many years prevented a clear epidemiological picture being drawn, many countries now have better monitoring and reporting systems in place.

Almost half of those who have died of AIDS and are currently infected with HIV or AIDS are women. Equally significant, and disturbing, is that a large number of children are not only becoming orphans but are also increasingly infected either at birth or shortly thereafter. One out of every third child born to a pregnant mother is likely to be infected. Drugs that can be given to pregnant HIV infected women are expensive: several developing countries have health budgets that allocate only one US dollar per person.

\section{STORY OF THE SHIFTING PARADIGMS}

In the early years of the epidemic, the HIV/AIDS problem came to be viewed in terms of 'sin' or 'moral retribution for bad behaviour'. With homosexuals, sex workers and intravenous drug users becoming disproportionately affected, the 'moral paradigm' predominated. As virologists developed a better understanding of the modes of transmission and virus replication, and with the infection entering the 
heterosexual population, a 'medical paradigm' emerged, albeit slowly.

In the late 1980 s and early 1990 s, social scientists, in particular, demonstrated how poverty, vulnerability, insecurity, denial of human rights and limited access to health services - all too ubiquitous in many developing countries in Asia, Africa and Latin America, and in pockets of developed countries - conspire to fuel the epidemic. The 'medical paradigm' soon gave way to a 'risk-vulnerability paradigm', which later became integrated into what is now broadly defined as the 'development paradigm'.

The historic United Nations General Assembly Special Session on AIDS held in New York in June 2001 underlined how the HIV/AIDS problem has emerged as a major developmental issue, threatening the well-being and security of nations and the people of the world, irrespective of race, nationality, colour or any other consideration. A truly global problem that demands no less than a global response - this was the message of the political leaders, health administrators, and activists who attended the session.

\section{CONCEPTUAL AND TERMINOLOGICAL PROBLEMS}

Throughout the epidemic, certain conceptual and terminological issues have continued to loom large. The issue of whether HIV causes AIDS or not, and whether people die of AIDS, has now entered the realm of politics with the present President of South Africa in disagreement with the medical establishment. Early preventive efforts concentrated on so-called 'high risk groups', with gay men, sex workers and intravenous drug users being classified as belonging to such groups. There was subsequently a shift to 'vulnerable' groups. When the infection entered the heterosexual community, some laws classified the wives of men who have multiple partners as a high-risk group. With HIV/AIDS being classified in some countries as a venereal disease or a sexually transmitted disease, persons who had become infected as a result of contaminated blood transfusions found themselves classified in the same category as those who had contracted HIV and STDs through casual sex.

Some of the conceptual and terminological issues surfaced during the UN General Assembly Special Session, with some Islamic nations objecting to the Conference documentation referring to drug use, casual sex and other forms of behaviour (such as, for example, sex work which was referred to as vulnerability due to means of livelihood) not acceptable to certain religions or social groups. Much time and effort were spent on finding neutral language, which, at the same time, did not result in diluting the message.

\section{SCOPE OF HUMAN RIGHTS IN THE CONTEXT OF HIV/AIDS}

From the very early case of the detection of AIDS among a group of homosexuals until the present time, human rights violations have been reported by persons with HIV/AIDS and their families or significant others. These range from denial of access to the health services and termination of employment to refusal of access to community wells to draw water for the daily needs. Persons with HIV/AIDS have been beaten to death as well - a recent tragic incident comes from Africa, where in response to international calls for people to be frank and open about their condition, an African activist admitted that she had AIDS but this turned out to be a fatal mistake.

The UN Centre convened an International Consultation on AIDS and Human Rights for Human Rights and WHO's Global Programme on AIDS in 1989. The report identified several human rights as set out in various international treaties that were relevant to the HIV/AIDS situation. Another followed this consultation in 1996 where international guidelines were formulated. At the UN General Assembly Special Session objections were raised to any mention in the final text of the report of this consultation due to the use of unacceptable language. Within the Asia and Pacific region, a series of regional workshops was organised by UNDP in 1986 to examine the HIV-related law and law reform issues, including human rights issues. One such regional workshop was held in Beijing before the famous women's conference and this marked the first occasion where a UN-sponsored activity held in China openly discussed human rights issues.

Among the human rights identified as being relevant to the HIV/AIDS context are the following:

- non-discrimination/equality before the law;

- privacy;

- liberty;

- freedom from inhuman/degrading treatment;

- freedom of movement;

- freedom from forced servitude;

- health;

- education/information;

- work;

- social security;

- seeking and enjoying asylum;

- marriage and founding a family.

The relevance of these rights to HIV/AIDS and their public health rationale are set out in the Annex to this article.

\section{APPLICATION OF HUMAN RIGHTS IN THE NATIONAL CONTEXT}

There are well-documented examples of how each of the rights listed above has posed problems to persons with HIV/AIDS in one or more countries. Space does not permit a detailed discussion: hence, it is proposed to list some of the common forms of restrictions placed upon persons with HIV/AIDS and provide selected examples from one country, namely India, of some of the practical situations where these restrictions have occurred. 
Restrictions placed upon persons with HIV/AIDS fall into the following broad categories:

(1) restrictions on the movement of persons across national frontiers;

(2) restrictions on freedom of internal travel due to compulsory hospitalisation or other reason such as quarantine or isolation;

(3) (4) restrictions on sexual behaviour;

(6) restrictions on donations of blood, semen, breastmilk or organs;

(8) restrictions on freedom of occupation; and

(9) other miscellaneous forms of restrictions.

Some restrictions have a valid public health rationale others do not. A number of considerations are taken into account in determining whether a particular restriction should be imposed or not. Among these are the following:

- medical, scientific, technological readiness/validity;

- legal, constitutional, ethical and human rights acceptability/compatibility (is it the least restrictive option?);

- cultural, social and religious acceptability;

- political expediency; and

- administrative and economic feasibility.

In India, testing of foreign students was a major controversial issue. African students, in particular, complained that they were being victimised. This was followed shortly thereafter by a draft bill seeking to prohibit Indian nationals from marrying foreigners. After much opposition, this bill was not proceeded with. A regulation was made under the Railways Act making it obligatory for a person with AIDS to inform the stationmaster of his or her condition and for such person to travel in isolation in a separate compartment. In a country with overcrowded trains, this made no sense at all. The regulation was subsequently repealed. The HIV/AIDS problem came up for consideration before the courts on a number of occasions. Activists and affected persons challenged compulsory detention orders. Public interest litigation instituted by a non-governmental organisation (NGO) sought to compel the Commissioner of Prisons to make condoms available in prisons, while another NGO intervened to prevent condoms being made available. In what turned out to be a controversial decision, the Supreme Court held that in the case of a HIV-infected person the right to marry remains suspended so long as he remains infected (which is in all probability life-long). This was a case where during a routine blood test a person was infected and his fiancée was informed by the hospital authorities, resulting in cancellation of the arrangements for the wedding. Apart from documented and reported cases, anecdotal evidence is available of persons being denied access to health care services, even to find a doctor who is available for a consultation. People have been removed from employment, their tenancy agreements cancelled and welfare benefits suspended: with India emerging as the new epicentre of the HIV/AIDS epidemic there are concerns that vulnerable groups who are disproportionately affected by the virus will continue to suffer more discrimination.

Attempts are now underway to address some of the human rights issues. NGOs are particularly active in lobbying for the rights of HIV/AIDS infected persons. A group of lawyers file court actions free of charge. The medical profession and hospital administrators are slowly responding to the emerging need to provide much needed medical services. Fortunately, the cost of some of the required drugs is relatively inexpensive.

\section{THE UNFINISHED AGENDA}

The dawn of a new century has posed a greater challenge than ever before to take decisive action to promote a human rights-based approach to the HIV/AIDS problem. Civilised societies the world over cannot but feel ashamed of their poor record to date. The conferment of rights and the protection of such rights are only part of a much larger and difficult agenda.

The unfinished agenda has many items. There is a need to improve the health and social infrastructure of developing countries where the majority of new infections occur. AIDS is, of course, not the only problem of concern. Malaria, for instance, kills 3,000 persons a day. The resurgence of TB in certain parts of the world poses a new challenge because of drug-resistant viruses. In the specific context of HIV/AIDS prevention, there is a need to improve access to safe blood supply systems; good quality and reasonably priced drugs are essential; condom availability needs to be scaled up; treatment and care must be universally available; and finally, education and information campaigns must seek to bridge the information gap that currently exists.

All in all, what is required is a concerted attack on the root causes of poverty, poor governance, and slow infrastructure development. A human rights-based approach that seeks to enhance the quality of life in all its dimensions must address economic, social, cultural, legal and religious aspects and spiritual values.

ANNEXE

HUMAN RIGHTS AND HIV / AIDS

HUMAN RIGHT

NON-DISCRIMINATION/ EQUALITY BEFORE THE LAW

PRIVACY

LIBERTY

\section{APPLICATION TO HIV / AIDS}

Promote access of disadvantaged groups to HIV prevention and care programmes.

Prevent discrimination against HIV + or those suspected in employment, travel, health care, education, social assistance. 
Prevent mandatory testing.

Prevent routine or hidden tests

Ensure confidentiality

Ensure informed consent before tests, treatment or research Prevent arrest/ detention on account of HIV status alone

Prevent isolation or segregation in administrative setting on account of HIV status alone

\section{PUBLIC HEALTH RATIONALE}

Preventing/care efforts should reach all, including those difficult to reach.

Almost no threat of transmission in these settings

Mandatory testing

Can never reveal identity of all HIV +

May involve false test results

Drives people away from prevention/health care efforts

Results in psycho trauma if no counselling

Involves diversion of resources better spent on education/health care

Detention/isolation

No public health rationale; does not prevent spread

Is costly and impracticable since life long

\section{HUMAN RIGHT}

\section{FREEDOM FROM INHUMAN/ DEGRADING TREATMENT}

\section{FREEDOM OF MOVEMENT}

FREEDOM FROM FORCED SERVITUDE

\section{APPLICATION TO HIV/AIDS}

Promote measures to protect against sexual violence/sexual coercion

Prevent compulsory isolation or segregation of prisoners HIV +

Prevent forced abortion/ sterilization of HIV + women

Prohibit testing of returning nationals

Prohibit testing of entering foreigners

Regarding cost of care, HIV/AIDS be treated the same as comparable diseases

Prevent trafficking in women, men or children

Prevent forced prostitution or involuntary servitude for sexual purposes

Prevent harmful traditional practices, e.g. marriage of minors, wife inheritance, and female genital mutilation.

\section{PUBLIC HEALTH RATIONALE}

Any coerced sex increases risk of transmission

No public health rationale for isolating prisoners; more useful to make available information, clean needles, bleach and condoms

Only 1 out of 3 babies born infected if mother infected, much less if AZT used

Exclusion does not prevent spread, as HIV is already present Exclusion gives false sense of security

Better to use resources on education/security

Any coerced sex increases risk of transmission

Difficulty of access for prevention and care

Harmful traditional practices can increase social and/or biological vulnerability.

\section{HUMAN RIGHT}

HEALTH

\section{EDUCATION/INFORMATION}

WORK

\section{APPLICATION TO HIV/AIDS}

Promote equal access for disadvantaged, vulnerable groups to HIV health prevention and care programmes

Prevent discrimination against HIV + persons in health care Promote confidentiality in health care setting

Promote blood safety through screening of all blood, body parts and fluids

Prevent equal access for disadvantaged, vulnerable groups to HIV prevention education/information

Prevent discrimination against HIV + people in access to education facilities

Prevent pre-employment or during employment mandatory testing

Prevent isolation or termination due to HIV status

Ensure reassignment/ accommodation according to health needs

Ensure same employment policies for HIV/AIDS as for any comparable disease

Ensure confidentiality in work place

\section{PUBLIC HEALTH RATIONALE}

Prevention/care should reach all people, including those difficult to reach

If use universal precautions, little risk of transmission

Should maintain confidence in health care

Prevention/care should reach all people, including those difficult to reach

Virtually no risk of transmission in educational setting with basic precautions

Almost no risk of transmission in work place with basic precautions

HIV + person can and should be productive for long time 
HUMAN RIGHT

\section{SOCIAL SECURITY}

SEEK AND ENJOY ASYLUM

MARRY AND FOUND A FAMILY

\section{APPLICATION TO HIV/AIDS}

Promote equal access of women to social security and other available benefits in case of termination of marriage/employment

Prevent discrimination for HIV + people in access to social security

Prohibit refoulment on basis of HIV status

Promote humane/generous grant of asylum for HIV +

Prevent pre-marital mandatory HIV testing

Prevent prenatal mandatory HIV testing

Provide information/ counselling regarding risks/prevention

\section{PUBLIC HEALTH RATIONALE}

Women should have alternative to relationships that threaten them with infection, and to support, if husband dies

$\mathrm{HIV}+$ people need means of support

No public health rationale to deny asylum

Refugee cannot return home to persecution

$\mathrm{HIV}+$ married people can practice safe sex

Only 1 in 3 babies born infected if mother infected, much less if AZT used.

Dr Dayanath Jayasuriya

Attorney-at-Law; Director-General, Securities and Exchange Commission of Sri Lanka.

This article is taken from a public lecture delivered at the Institute of Advanced Legal Studies on 4 July 2001

\title{
Ireland
}

\section{Rogue directors - time to change careers?}

\author{
by Pat Igoe
}

I

n October a former leading member of the Irish Brokers Association, Tony Taylor, was sentenced by a Dublin court to five years in jail for fraud and related offences. Businessmen finding themselves on the wrong side of prison walls in Ireland are no longer the stuff of fantasy. New laws are now fast demanding new respect.

Earlier this year, the UK Trade and Industry Secretary, Patricia Hewitt, received a 559-page report from the Company Law Review Steering Group which, in the group's words, provided an 'opportunity to bring British company law from the nineteenth to the twenty-first century'. Similar and possibly even more significant improvements are being put in place in Ireland. They are long overdue.

Laws that are not enforced or enforceable fall into disrepute and then ridicule. Prior to the enactment this year of the Company Law Enforcement Act, the Companies Code was boring and turgid and too often ignored. It is still boring and turgid, but the new penalties for infringements by businessmen are real. Restriction and disqualification from acting as directors, and personal exposure of wrongdoings, will now be real risks and not just subjects for seminars attended mainly by academic lawyers.

Company directors queuing before the District Court and mumbling when their case is called that they thought that their accountants had filed the annual returns get short shift. In addition to the cost and inconvenience of spending up to half a day in court waiting for their case to come on, erring businessmen have found themselves facing fines averaging IR£ 400 or 10 days in prison - and this at the venial end of the scale of corporate wrong-doing.

The Companies Act 1963 in Ireland (which, incidentally, is substantially modelled on the British Companies Act 1948) probably has a greater number of criminal sanctions that any other Act on the statute book. Despite this, up until recently nobody greatly cared, and enforcement was regarded mainly as a private matter. Now all is changed, and changed utterly: enter a serious system of enforcement regime, exit the ancien regime.

The Company Law Enforcement Act complements legislation which established the Criminal Assets Bureau (CAB) five years ago. In its current annual report, the $\mathrm{CAB}$ reported that the High Court made 19 orders freezing assets which were shown, on the civil standard of proof, to be the proceeds of crime. The assets exceeded IR£3,900,000 in value.

The $\mathrm{CAB}$ is also charged with instituting tax collection enforcement proceedings on moneys derived from suspected criminal activity. The Ireland of recent financial scandals, with tribunals established by Parliament uncovering murky dealing in high places, and where the circumstances of the death of murdered journalist Veronica Guerin are still clearly remembered, is no longer a tolerant environment towards delinquent business people. Like drink driving, commercial crime is no longer regarded as ' $\mathrm{OK}$ '. 